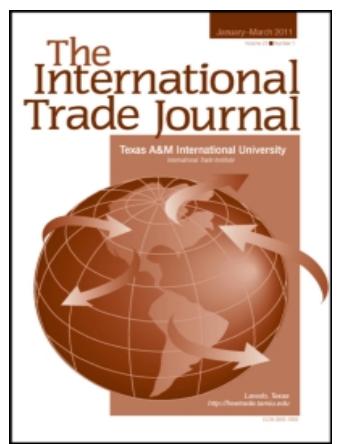

The International Trade Journal

\title{
Determinants of Intra-GCC Food Trade
}

\section{Simeon Kaitibie \& Manitra A. Rakotoarisoa}

To cite this article: Simeon Kaitibie \& Manitra A. Rakotoarisoa (2017) Determinants of Intra-GCC Food Trade, The International Trade Journal, 31:3, 272-293, DOI: 10.1080/08853908.2017.1288182

To link to this article: https://doi.org/10.1080/08853908.2017.1288182

册 Published online: 17 Mar 2017.

Submit your article to this journal $₫$

Џll Article views: 182

Q View related articles $₫$

View Crossmark data $\asymp$

4 Citing articles: 4 View citing articles 준 


\title{
Determinants of Intra-GCC Food Trade
}

\author{
Simeon Kaitibie ${ }^{\mathrm{a}}$ and Manitra A. Rakotoarisoa ${ }^{\mathrm{b}}$ \\ aDepartment of Finance and Economics, Qatar University, Doha, Qatar; ${ }^{\mathrm{b} T r a d e}$ and Markets Division, \\ Food and Agriculture Organization of the United Nations, Rome, Italy
}

\begin{abstract}
Using panel data for six Gulf Cooperation Council (GCC) countries from 1995-2014, we assess the impacts of several major economic variables on intra-GCC food exports, and on GCC food exports to the world. The GCC customs union had minimal impact on intra-GCC food exports, but occasioned a significant reduction in GCC food exports. Unlike GCC food exports, intra-GCC food exports occurred among countries with similar relative factor endowments, in agreement with the Linder Hypothesis. Rising incomes and exchange rates played significant roles in both intra-GCC food exports and GCC food exports, while distance has lost its once-dominant role.
\end{abstract}

\section{KEYWORDS}

Customs union; food export; gravity model; Gulf Cooperation Council; relative factor endowment

\section{Introduction}

The Gulf Cooperation Council (GCC) was founded in 1981 to foster coordination, integration, and interconnection among member countries Bahrain, Kuwait, Oman, Saudi Arabia, Qatar, and United Arab Emirates. On January 1, 2003, the GCC adopted a customs union. This allowed the regional grouping to institute a common external tariff of $5 \%$ on food items while dismantling all tariffs among member countries. Theories and evidence show that dismantling of tariffs within customs unions leads to increasing trade within the customs union, while discouraging trade with non-member countries (Syropoulos 1999; Williamson and Bottrill 1971). Regional trade agreements tend to increase welfare among member countries (Robinson and Thierfelder 2002). Countries will gain when tariffs are lowered or eliminated within customs unions, especially if the domestically produced commodity and the commodity they import from the trading partner are net substitutes (McMillan and McCann 1981).

In 2010, GCC food imports accounted for nearly $70 \%$ of total food requirement (Alpen Capital 2015), and with the region's fast-rising GDP and populations, food import is projected to increase to US $\$ 53$ billion by the year 2020 (Economist Intelligence Unit 2010). For instance, according to the 
World Bank (2012), Arab countries constitute the largest bloc of wheat importers, and they hold only $10 \%$ of the world's stock of wheat. With such a high food demand from the already high food import-dependent GCC countries, GCC governments ask how the adoption of a customs union affects their intra-GCC food trade and food security. To our knowledge, no study has addressed this question.

This study evaluates the determinants of food trade in the GCC customs union, including the impact of the GCC customs union using an augmented gravity model. We also employ the methods of Helpman (1987) to investigate the impacts of relative differences in per capita GDP and the relative sizes of the economies on intra-GCC trade. Theoretically, adoption of the customs union by the GCC should lead to a large increase in intraGCC food exports for the following reasons: first, it provides significant access to larger domestic supplies in Saudi Arabia, which is endowed with more agricultural resources than all of the other GCC countries. Adoption of the customs union may lead to both trade creation and trade diversion. Trade creation may arise because small countries with very limited amounts of agricultural resources, such as Bahrain and Qatar, would now derive advantage in importing food from neighboring Saudi Arabia and the United Arab Emirates instead of continuing to undertake costly limited domestic food production. In other words, trade creation allows countries to shift from high-cost domestic production to supplies from lower-cost production in partner countries in the customs union. Second, trade diversion may occur because proximity to other GCC agricultural production may provide more reliable supply of some food items, especially vegetables previously imported from overseas. Notwithstanding, there has been very little empirical research on intra-GCC food exports, especially as it relates to the customs union. This is the first such assessment.

\section{Review of relevant literature}

Many studies have focused on the effects of customs unions or general free trade agreements on trade. Yu and Scully (1975) proved that customs unionled trade, especially trade diversion, might generate positive welfare changes. In a study on a bilateral trade agreement between Canada and the U.S., Furtan and van Melle (2004) observed that the persistence of non-tariff barriers in a free trade situation reduced the quantities traded for a select group of agricultural commodities. Ornelas (2007) envisioned a system of rent extraction in which countries within a customs unions shift profits from excluded countries when they coordinate external tariffs. Excluded countries might be tempted to support free trade because they may feel left out by trade diversion. 
Studying the effects of customs union on intra-GCC food trade requires special attention, because intra-GCC food export trade differs from those of other countries and free trade zones cited in the literature. Some GCC countries currently have high dependence on domestic production in neighboring GCC countries. For example, in 2011, Qatari imports of food from Saudi Arabia satisfied domestic demand at high levels; $81 \%$ of potatoes, $96 \%$ of beans, $94 \%$ of pumpkins, $87 \%$ of cucumbers, $86 \%$ of watermelons, $77 \%$ of eggplants, and $68 \%$ of eggplants were imported from Saudi Arabia (Qatar Statistics Authority 2012). Additionally, what distinguishes the GCC from other free trade zones is that the countries have similar customs, languages, and cross-border familial relationships which, for generations, have favored cross-border trades. In such situations, the customs union could have been a mere formalization of ongoing trade activities, instead of the creation of new trade opportunities.

We employ the gravity model (Anderson and van Wincoop 2003), which traces its roots to early seminal work such as Bergstrand (1985) and Tinbergen (1962). In spite of the limited amount of empirical work on intra-GCC food trade, the literature on studies estimating the determinants of trade within trade agreement zones abound. For example, Okabe and Urata (2014) assessed the impact of ASEAN Free Trade Area (AFTA) on trade within ASEAN using the gravity model; the study found significant and positive trade creation effects. Serlenga and Shin (2007) used the gravity model to assess intra-EU trade. Jayasinghe and Sarker (2008) used an extended gravity model to analyze trade creation and diversion effects of the North American Free Trade Agreement (NAFTA). Finally, Lambert and McKoy (2009) used a gravity model to assess the incidence of trade creation and trade diversion in preferential trade agreements.

Similarly, using the gravity model and disaggregated (HS6) trade data, Cipollina and Salvatici (2010) analyzed the impacts of preferences on EU imports and concluded that preferences influence the extensive margin of trade for the EU food imports from developing countries. They estimated, rather than assigning, the extent of the preference margin using the ratio of the highest applied duty for all exporters to the actual tariff for each commodity and proceeded in a two-stage Heckman estimation of the impacts of the preference margins on trade to deal with zero trade flows. Ghazalian, Larue, and Gervais (2011) used commodity-specific gravity equation to show the evidence that, for meat commodities, the EU's tariff-free access and the NAFTA's nontariff provisions are the main determinants of intra-trade promotion for these RTAs. Olper and Raimondi (2009) focused on processed food trade and included an iceberg trade cost in the gravity model to show that trade policy remains the main determinant of trade costs for trade between developed and emerging economies; they also found that, in both developed and developing countries, geographical and historical factors affect 
trade cost and trade. Sun and Reed (2010) estimated the effect of free trade agreements on agricultural trade. Their analysis revealed that some free trade agreements generated large increases in agricultural trade, with little empirical support for the lowering of trade barriers. An analysis of agro-food trade in the EU (Bojnec and Ferto 2016) revealed rising levels of intra-industry trade from EU membership and that agro-food exports were of higher quality than imports of similar food items.

GCC economies appear to have generally similar demand structures. The Linder Hypothesis (Linder 1961) suggests that, as economies become similar by way of demand structure, they will trade more with each other. Per capita income is commonly used as a proxy for demand structure because highincome countries tend to develop comparative advantage in producing highquality goods, which are in high demand in their domestic markets (Hallak 2010). As the sizes of their economies become similar, countries tend to trade more with each other (Helpman 1987).

\section{Methods and data}

\section{Modeling issues}

The dataset developed for this study was compiled in a panel data format; we therefore anticipate several estimation concerns. First are the lesser problems of autocorrelation and heteroscedasticity, respectively observed in time-series and cross-section data, which render the ordinary least-squares estimator inefficient. Second, there is a possibility that unobserved individual-specific disturbances might be correlated with the regressors. Third, in the event that we fail to reject independence between individual-specific disturbances and the regressors, the applicable fixed-effects model may not be appropriate if the model includes time-invariant regressors. These problems suggest that one must carefully select the appropriate analytical approach for panel data analysis.

To illustrate the problem and analytical approach, we first consider the following cross-section time-series model:

$$
\begin{aligned}
& Y_{i t}=\mathbf{X}_{i t} \beta+\mathbf{Z}_{i} \delta+\varepsilon_{i t} \forall(i=1, \ldots ., N ; t=1, \ldots ., T) \\
& \varepsilon_{i t}=\alpha_{i}+\eta_{i t}
\end{aligned}
$$

where $Y$ is the dependent variable, $X$ is a TN $\mathrm{x} \mathrm{k}$ matrix of regressors, which hence vary over time and cross-section, and $Z$ is a TN $x \mathrm{~g}$ matrix of timeinvariant regressors. We make the assumption that $\mathrm{E}\left(\eta_{\mathrm{it}} \mid \mathrm{X}_{\mathrm{it}}, \mathrm{Z}_{\mathrm{i}}\right)=0$ and $\mathrm{Var}$ $\left(\eta_{i t} \mid X_{i t}, Z_{i}\right)=\sigma_{\eta}^{2}$. The term $\alpha_{i}$ is a time-invariant random disturbance, which is independently distributed across cross-sections and has variance $\sigma_{\alpha}^{2}$. However, it is quite possible that $\alpha_{i}$ is correlated with all or some regressors such that $\mathrm{E}\left(\alpha_{\mathrm{i}} \mid \mathrm{X}_{\mathrm{it}}, \mathrm{Z}_{\mathrm{i}}\right) \neq 0$, which consequently implies that $\mathrm{E}\left(\varepsilon_{\mathrm{it}} \mid \mathrm{X}_{\mathrm{i}}, \mathrm{Z}_{\mathrm{i}}\right) \neq 0$. If 
these assumptions hold, the random-effects estimator is no longer consistent. The fixed-effects estimator, though consistent, is not capable of estimating coefficients for the time-invariant $Z_{i}$ variables.

To overcome these problems, estimators have been developed for different situations by Serlenga and Shin (2007), Plumper and Troger (2007), Amemiya and MaCurdy (1986), and Hausman and Taylor (1981). The CCEP-HT approach of Serlenga and Shin (2007) accounts for the existence of both observed and unobserved common factors whose individual responses are allowed to be heterogeneous. The fixed-effects vector decomposition (FEVD) estimator of Plumper and Troger (2007) does not require prior knowledge of correlation between $\alpha_{i}$ and the regressors, and it estimates coefficients for time-invariant variables. The Amemiya and MaCurdy (1986) approach provides an instrumental variable estimator for error components estimation based on different assumptions about the sources of endogeneity as well as the variance-covariance properties of the disturbances. Finally, the Hausman-Taylor estimator (Hausman and Taylor 1981) provides an efficient estimator when $\alpha_{i}$ is correlated with the regressors while, at the same time, allowing for the estimation of coefficients for time-invariant regressors in panel data. The analytical approach we utilized follows the following general steps: First, we estimated a random-effects model. Second, we estimated a fixed-effects model. Third, we conducted a Sargan-Hansen test (Hansen 1982; Sargan 1958) to determine if the random-effects estimator is consistent. Fourth, because the Sargan-Hansen test revealed that the random-effects estimator is not consistent, we estimated a Hausman-Taylor model due to the presence of time-invariant regressors such as distance and land borders.

In the test for functional form noted earlier, if the null hypothesis that the $\alpha_{i}$ disturbances are not correlated with the regressors is not rejected, conventional wisdom is that the random-effects estimator is deemed most appropriate. In reality, the random-effects estimator would be asymptotically efficient whereas the fixed-effects estimator would be consistent and unbiased but not efficient (Hausman 1978). If the null hypothesis is rejected, the random-effects estimator is both biased and inconsistent. However, because the fixed-effects estimator does not estimate coefficients for timeinvariant regressors, we overcome the problem by presenting outputs from the Hausman-Taylor estimator.

To illustrate the Hausman-Taylor concept, we reiterate that some explanatory variables are of the $X_{i t}$ types, varying over time and cross-section, while others are of the time-invariant $Z_{i}$ types. The Hausman-Taylor model is based on the concept of instrumental variables. We assume that $X_{i t}=\left[X_{1 i t}\right.$, $\left.\mathrm{X}_{2 \mathrm{it}}\right]$ and $\mathrm{Z}_{\mathrm{i}}=\left[\mathrm{Z}_{1 \mathrm{i}}, \mathrm{Z}_{2 \mathrm{i}}\right]$. We further assume that the regressors $\mathrm{X}_{1 \mathrm{it}}$ and $\mathrm{Z}_{1 \mathrm{i}}$ are not correlated with $\alpha_{i}$ while $X_{2 i t}$ and $Z_{2 i}$ are correlated with $\alpha_{i}$. We rewrite Equation 1 as 


$$
\begin{aligned}
Y_{i t} & =\mathbf{X}_{1 i t} \beta_{1}+X_{2 i t} \beta_{2}+\mathbf{Z}_{1 i} \delta_{1}+Z_{2 i} \delta_{2}+\varepsilon_{i t} \forall\{(i=1, \ldots ., N ; \\
t & =1, \ldots ., T)\} ; \varepsilon_{i t}=\alpha_{i}+\eta_{i t}
\end{aligned}
$$

where $E\left[\alpha_{i} \mid X_{1 i t}, Z_{1 i}\right]=0$, but $E\left[\alpha_{i} \mid X_{2 i t}, Z_{2 i}\right] \neq 0$. In addition, $\operatorname{Var}\left[\alpha_{i} \mid X_{i t}, Z_{i}\right]=\sigma_{\alpha}^{2}$ and $\operatorname{Var}\left[\varepsilon_{i t} \mid X_{i t}, Z_{i}\right]=\sigma^{2}=\sigma_{\alpha}^{2}+\sigma_{\eta}^{2}$. Finally, $\operatorname{corr}\left[\varepsilon_{i t}, \varepsilon_{i s} \mid X_{i t}, Z_{i}\right]=\rho=\sigma_{\alpha}^{2} / \sigma^{2}$. To obtain consistent estimates of $\beta_{1}, \beta_{2}, \delta_{1}$ and $\delta_{2}$, we use differences from the temporal means of $Y$ and $X$ variables, along with instruments for $X$ and $Z$ variables. The explanatory variables and their expected impacts are reported in Table 1.

\section{The gravity model of intra-GCC food exports}

To estimate the determinants of intra-GCC food export trade, we adopted variables from the classical gravity model of trade, while augmenting these with other economics variables from the trade literature. Generally, trade flows are differentiated by origin (Bergstrand 1985) and several studies have followed through by using exports as dependent variable (Anderson and van Wincoop 2003; McCallum 1995). Some GCC countries like Oman, United Arab Emirates, and Saudi Arabia produce significant amounts of food; with the relative ease of movement across borders, food from these countries are shipped to higher-priced markets like Doha, Qatar. Consequently, we specify a gravity model of intra-GCC food exports from country $i$ to country $j$ in period $t$ as:

$$
\begin{aligned}
\ln \left(\text { EXPORT }_{i j t}\right) & =\beta_{0}+\beta_{1} \ln \left(\text { TGDP }_{i j t}\right)+\beta_{2}\left(\text { POPPTN }_{j t}\right)+\beta_{3} \ln \left(\mathrm{DIST}_{\mathrm{ij}}\right) \\
& +\beta_{4} \ln \left(\text { BORDER }_{i j}\right)+\beta_{5}\left(\mathrm{CUNION}_{\mathrm{ijt}}\right)+\beta_{6} \ln \left(\text { RFE }_{i j t}\right) \\
& +\beta_{7} \ln \left(\text { EXCHRR }_{i j t}\right)+\alpha_{i j}+\eta_{i j t}
\end{aligned}
$$

where the dependent variable is the value of food exports from country $i$ to country $j$. TGDP is the sum of the GDPs of the trading partners. Representing the size of the economy in the gravity model, total GDP has a positive effect on food exports. Alongside income, population is a major driver of demand. POPPTN measures the population of the food importing country. In the intra-GCC model, DIST measures road distance between the capitals of the exporter and the importer because most intra-GCC food shipment is by road transport. Countries would trade more with each other if they were closer to each other and farther away from other trading partners. BORDER is a categorical variable that takes the value of 1 when a land border exists between trading partners and 0 otherwise. It is expected that trade between GCC countries that are adjacent to each other will be higher than trade with other countries; hence, the parameter is expected to be positive. DIST and BORDER are time-invariant variables. 
The variable CUNION is also a categorical variable that takes the value of 1 if both trading partners are members of the GCC customs union and 0 otherwise. The GCC customs union came into existence in 2003, and all GCC countries acceded at the same time. The GCC variable is expected to be positive because the customs union would remove the last vestiges of trade barriers along borders in the GCC.

Notable differences in per capita GDP reflect relative factor endowment (RFE) between GCC countries or the demand structure of the respective economies. The economic measure can be calculated as the log of the absolute value of the difference between per capita GDPs of each set of bilateral trading partners (Helpman 1987), such that

$$
\ln \left[R F E_{i j t}\right]=\mid \text { per capita } \mathrm{GDP}_{\mathrm{it}} \text { - per capita } \mathrm{GDP}_{\mathrm{jt}} \mid .
$$

If the RFE is large, it means that there is a large difference in per capita GDP and hence dissimilar demand structures between trading partners. On the other hand, the RFE value would be small if the demand structures are similar. As suggested by the Linder Hypothesis, trade increases among countries with similar demand structures. Under this scenario, the coefficient will be negative.

The trade literature is replete with references to possible determinants of trade. For example, Egger and Pfaffermayr (2003) suggest that exchange rate has a positive effect on trade if the value of exports is much larger than the value of imports. Given the preponderance of fixed exchange rates in the GCC, we used the ratio of nominal effective exchange rates instead of bilateral exchange rates. The nominal effective exchange rate is a tradeweighted currency index that appreciates as the domestic currency appreciates and depreciates as the domestic currency depreciates. Depreciation in the domestic currency makes exports more competitive; therefore, exchange rate (EXCHRR in Equation 3) is expected to have a positive effect in the model. The explanatory variables and their expected impacts are reported in Table 1.

\section{The gravity model of GCC food exports}

For GCC food exports to the rest of the world, the gravity model in Equation 3 was reestimated, using appropriate data and the attendant dependent and explanatory variables. Similar to the intra-GCC model, the dependent variable is the value of food exports. It is expected that food exports from the GCC will be positively impacted by total GDP and size of the population in the food-importing country. Unlike the intra-GCC model, DIST was measured in air distance between capital cities. Nevertheless, we expect that distance will have a negative effect on exports. In this model, BORDER 


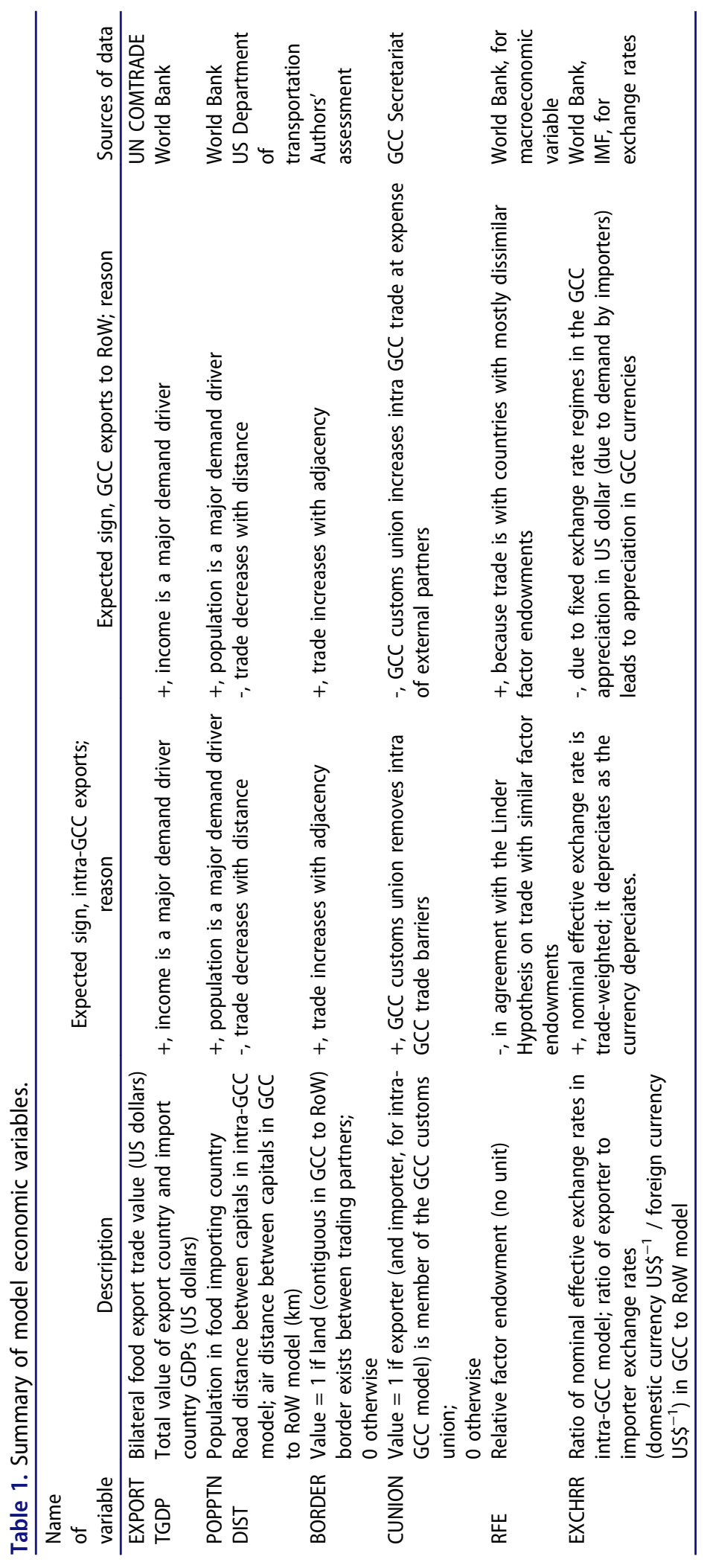


takes a slightly different definition from the intra-GCC model-though still a categorical variable, it takes the value of 1 when a contiguous border exits between trading partners and 0 otherwise. The contiguous nature of the border takes into account other positive effects of adjacency. If most of the GCC food exports are to countries outside of GCC borders, the variable will be negative.

The CUNION variable indicates whether the food-exporting country is a member of the GCC customs union. Membership of the customs union may foster intra-GCC food exports, at the expense of exports to countries external to the GCC. Consequently, the customs union will have a negative impact on food exports to the rest of the world. As the GCC trades with countries large and small around the world, relative factor endowments will differ among trading partners. According to the HeckscherOhlin theory of trade, as resource endowments become more dissimilar, countries will produce (and export) goods in which they hold abundance of specific resources. On the other hand, if the Linder Hypothesis is true, bilateral export trade will increase between countries with similar factor endowments. Factor endowments are unlikely to be similar with respect to most of the GCC's external trading partners; hence, in the RoW model, we expect a positive relationship between food exports and factor endowments, in support of the aforementioned Heckscher-Ohlin theory.

Finally, we use the ratio of bilateral exchange rates (i.e., exporter US\$ ${ }^{-1} /$ importer US $^{-1}$ ) to illustrate the effect of exchange rate on food exports. As the importers' demand for dollars rises over time, the dollar appreciates in value relative to their domestic currencies. By extension, GCC currencies that are pegged to the U.S. dollar also appreciate in value relative to the trading partners' domestic currencies. Thus, the coefficient may reveal a negative relationship between food exports and exchange rate.

\section{Sources of data}

Aggregate food trade data for intra-GCC food exports were obtained from UN Commodity Trade Statistics (UN COMTRADE) database. Additional data, such as population, GDP, and per capita GDP, were obtained from the World Bank country data. Nominal effective exchange rates for Bahrain, Oman, Qatar, Saudi Arabia, and United Arab Emirates were obtained from the International Monetary Fund, whereas nominal effective exchange rate for Kuwait was obtained from Reuters. Every effort was made to develop a complete dataset from 1995 to 2014, but that was not always the case, because not all countries reported trade data for all of the years. In the end, we developed an unbalanced panel dataset.

Means of some variables in the model are presented in Table 2. They include values of food exports, distance, GDPs of food exporters and importers, exchange rate ratio, and relative factor endowments. Qatar exports the 


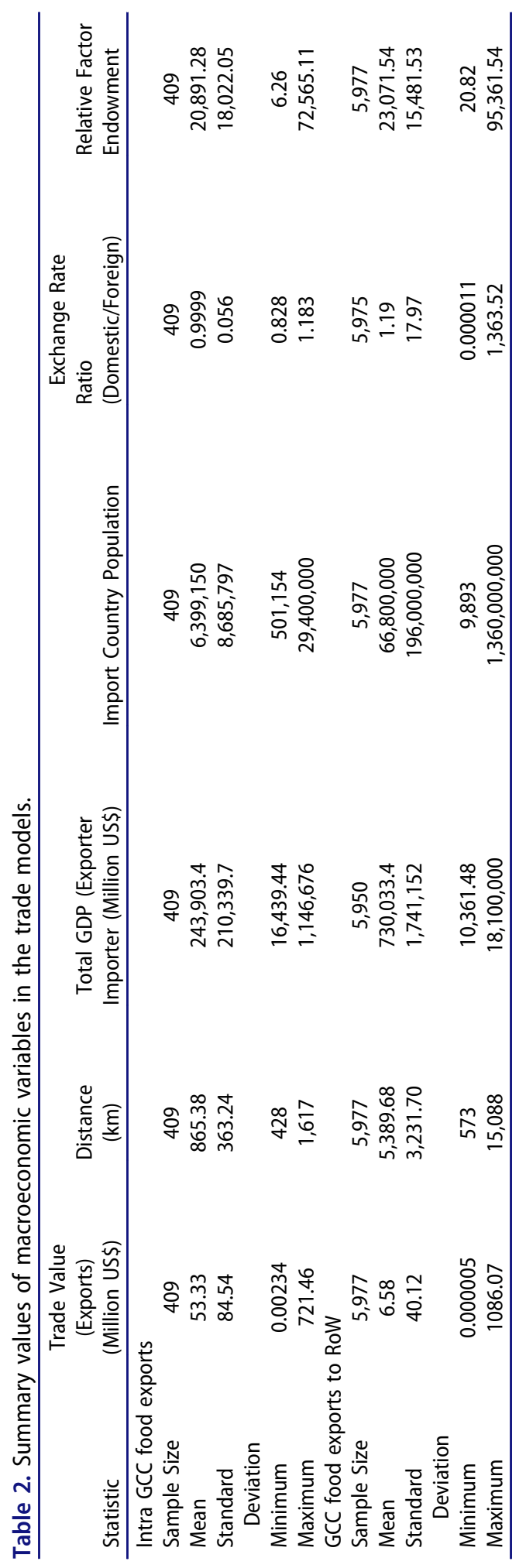


least amount of food while Saudi Arabia exports the most food within the GCC. However, Saudi Arabia occasionally slaps export restrictions on food exports, including well-publicized episodes in 2012 when fresh poultry and five field crops were explicitly banned from the export market.

The average GDP and recent data reported elsewhere reveal that Saudi Arabia is the largest economy by far, followed by United Arab Emirates and Qatar, although the latter has the highest per capita income in the world. Bahrain remains the smallest country and the smallest economy. Food items to/from Qatar travel the shortest distance because Qatar shares a land border with Saudi Arabia and contagious borders with Bahrain and United Arab Emirates. On the other hand, Omani-traded food items travelled the longest average distance. Qatar, with the highest per capita GDP in the GCC, records the highest average RFE value, while Oman records the lowest value.

\section{Model estimation}

First, we estimated the econometric relationship in Equation 3 for intra-GCC food exports and GCC food exports to the world using a fixed-effects estimator, followed by a random-effects estimator. The Sargan-Hansen test revealed that the fixed-effects estimator is most appropriate for both models. However, as previously mentioned, the fixed-effects estimator does not provide parameter estimates for time-invariant variables such as distance and the presence of a land border. To be able to provide parameter estimates for both time-invariant variables distance and land border, we reestimated both models using the Hausman-Taylor estimator.

In order to estimate the Hausman-Taylor model, we needed to identify the set of exogenous and endogenous explanatory variables. Based on extensive knowledge of the explanatory variables, total GDP, import country population, relative factor endowment, and exchange rate were selected as endogenous variables, whereas membership in the customs union, border, and distance between trading partners constitute the exogenous set. Therefore, following Equation 2, the $\mathrm{X}$ and $\mathrm{Z}$ vectors were disaggregated as follows: $\boldsymbol{X}_{1 \mathrm{it}}=$ [CUNION]; $\boldsymbol{X}_{2 \mathrm{it}}=$ [TGDP, POPPTN, RFE, EXCHRR]; $\boldsymbol{Z}_{1 \mathrm{i}}=$ [DIST, BORDER]; and $Z_{2 \mathrm{i}}=$ []. A similar disaggregation was made for both the intra-GCC food export model and the model of GCC food exports to the rest of the world.

In theory, it is possible for population to have a collinear relationship with other explanatory variables such as total GDP and relative factor endowment. In consequence, we provide a set of Pearson product-moment correlation coefficients in Table 3 in order to identify and rectify such possible relationships. Indeed, especially with respect to the intra-GCC export model, total GDP and import country population have relatively high positive correlation. The possibility exists that affected coefficients may be unstable, with 


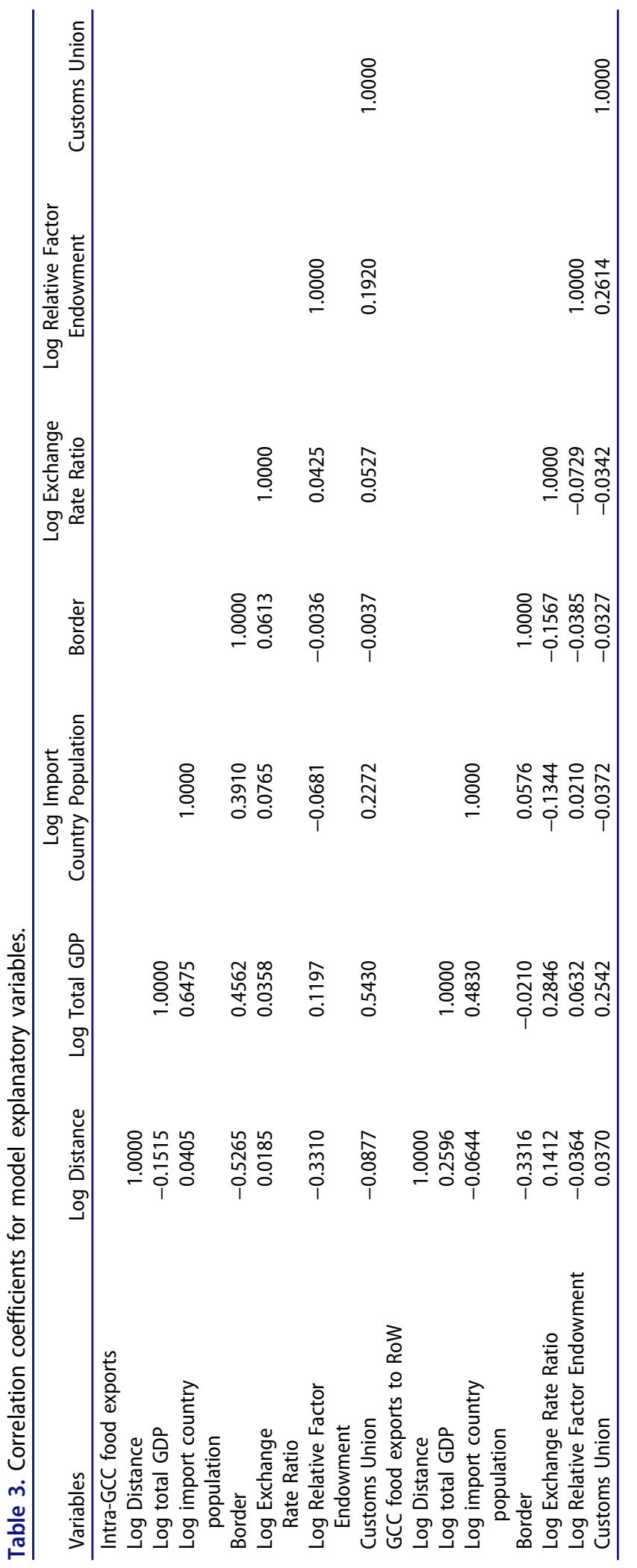


incorrect signs and large standard errors. Therefore, we estimated two Hausman-Taylor models: Equation 3, and a reduced model that excludes import country population as an explanatory variable. All models were estimated using StataTM 14 software.

\section{Results and discussion}

We present parameter estimates for the fixed-effects estimator, the randomeffects estimator, and the Hausman-Taylor estimators for Equation 3 in Tables 4 and 5. In both cases, Sargan Hansen tests revealed that the random-effects estimator is not consistent. Consequently, we used the Hausman-Taylor model in order to estimate parameters for the time-invariant variables.

\section{Determinants of total intra-GCC food exports}

In Table 4, we present parameter estimates for the fixed-effects estimator, the random-effects estimator, and the Hausman-Taylor estimator. The model from Equation 3 evaluates the determinants of intra-GCC food exports. The Sargan-Hansen test $\left(\chi^{2}=14.341\right.$; -value $\left.=0.0136\right)$ revealed that the randomeffects estimator is not consistent. As a result, the explanation of the determinants of intra-GCC exports therefore focuses on the parameter estimates of the Hausman-Taylor estimator; i.e., Hausman-Taylor (1). The factors most likely to affect intra-GCC food exports are total GDP, relative factor endowment, exchange rate, and to a lesser extent, import country population.

Total GDP is a highly significant determinant of aggregate intra-GCC food trade. A $1 \%$ increase in total GDP will lead to approximately $0.70 \%$ increase in intra-GCC food exports. The elasticity value reveals a less-than-proportionate increase in food exports. Income is one of the main drivers of food demand, and this is confirmed here and in other studies (e.g., Lambert and McKoy 2009). Specifically, a study on intra-EU trade (Serlenga and Shin 2007) found total GDP to be positive and statistically significant. The GCC countries have experienced large increases in income over the years, and this has increased demand for different kinds of food items.

Import country population, another known demand driver, is positive and yet weakly statistically significant. As populations rise, there are expectations of higher food demand and hence food imports to meet the demand. For example, between December 2015 and December 2016, the population of the State of Qatar increased by 7.3\%. This calls for increased domestic production or increased flow of imports. The GCC region has large populations of expatriates from different countries, including India, Nepal, Sri Lanka, Bangladesh, Egypt, and the Philippines. Due to rising demand for specific home-country food items, GCC countries routinely oblige with significant 


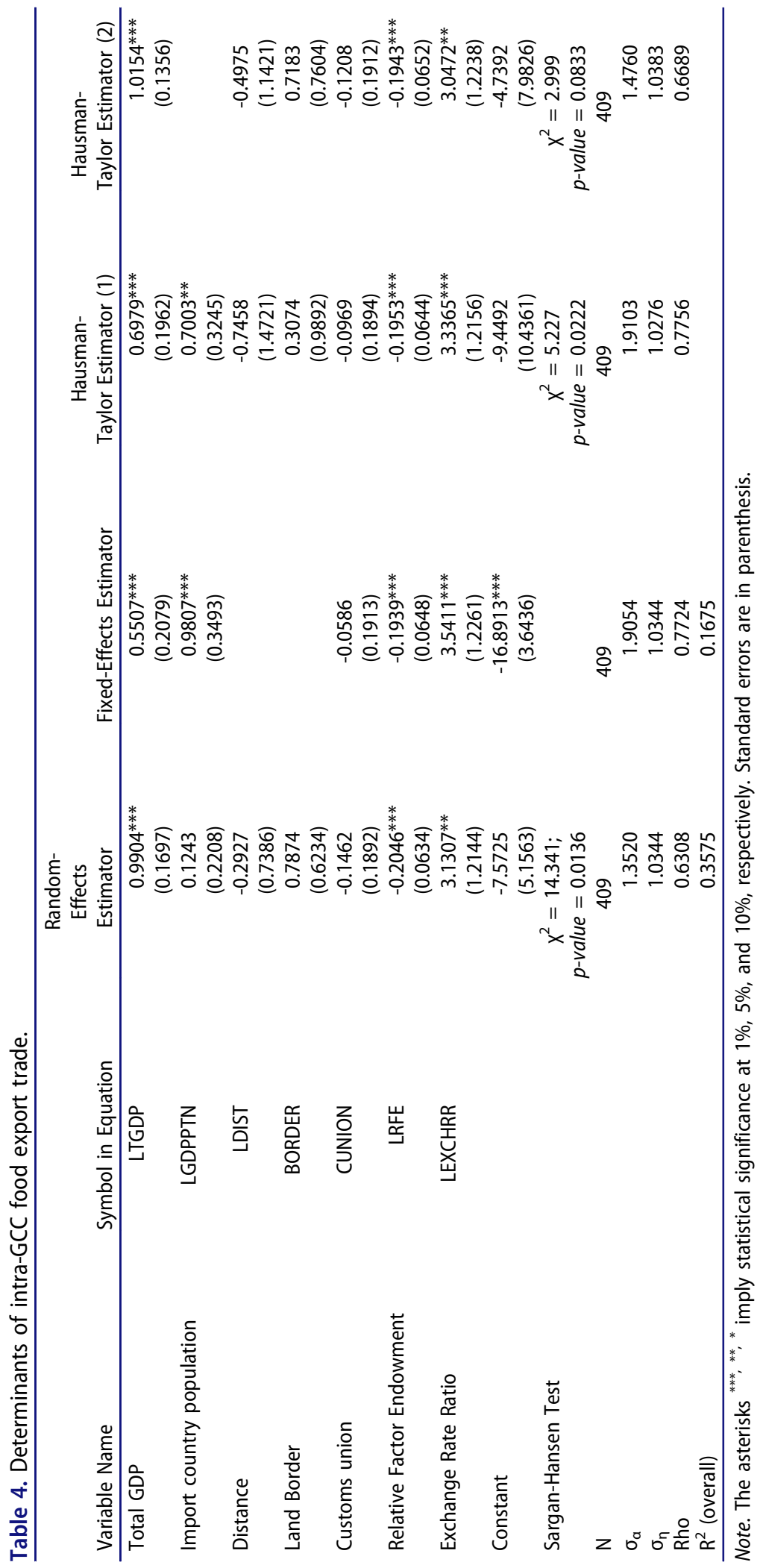




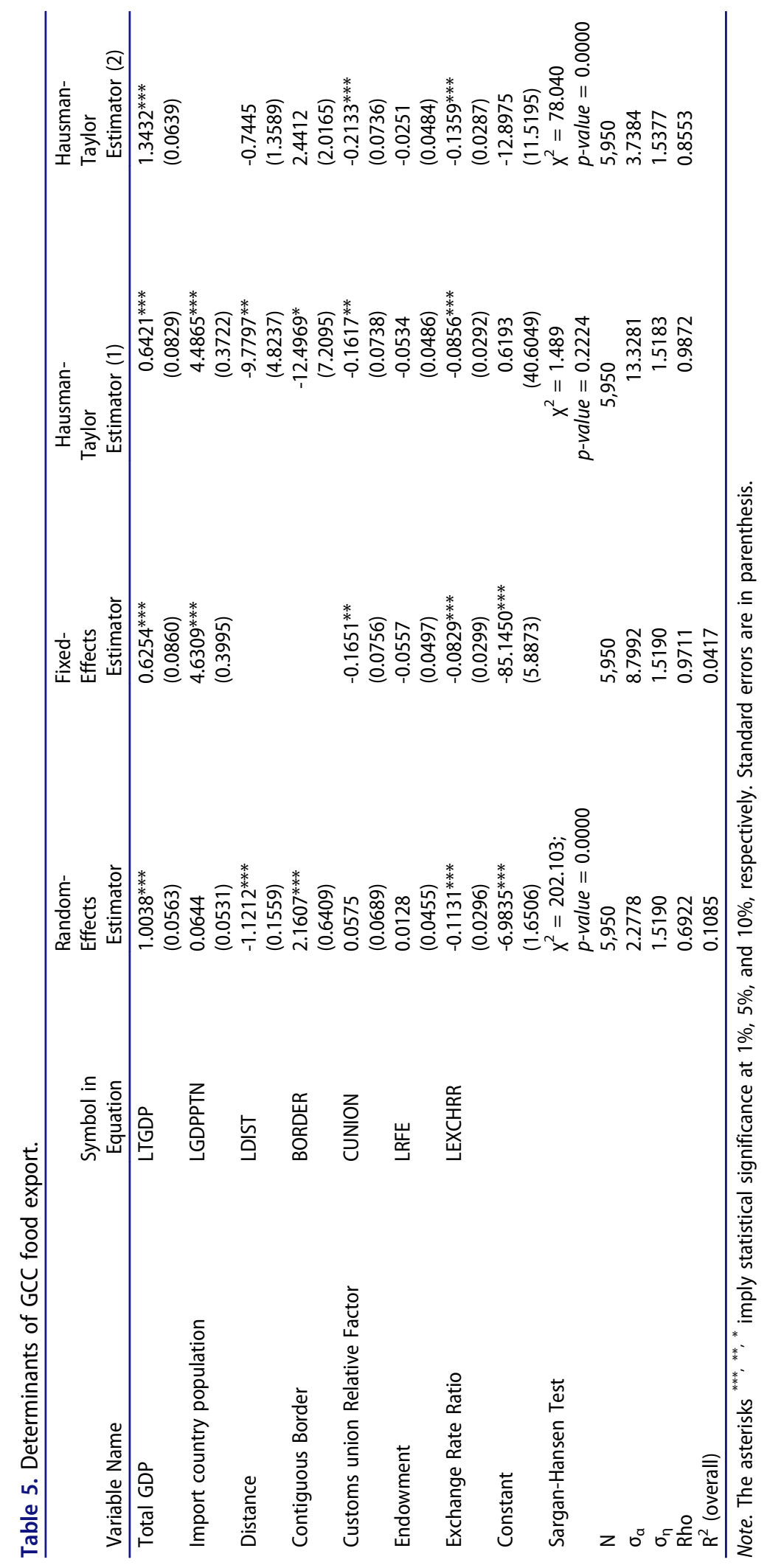


amounts of food imports from these countries. The Qatar food security master plan envisaged a situation of new food preferences for the diverse expatriate populations, and appropriately planned for it through imports and expanded domestic production (QNFSP 2013).

The marginal impact of distance on total food trade within the GCC is expectedly negative, but not statistically significant. The insignificant change in food export flows due to distance reflects the adjacency of Saudi Arabia, the largest exporter to the other GCC countries. In addition, the GCC area is relatively small, such that road distances for food transportation are relatively short. In a study of intra-EU trade, distance was negative and statistically significant (Serlenga and Shin 2007). Distance was also negative and statistically significant in intra-ASEAN trade (Okabe and Urata 2014), as well as in intra-industry agri-food trade in Visegrad countries (Jámbor 2014). It is worth noting that both the EU and ASEAN are significantly larger free trade areas than the GCC. Hence, intra-EU and intra-ASEAN food exports cover considerably longer distances than in the GCC.

The adjacency variable, BORDER, determines whether trade is higher between countries sharing a land border where it is so much easier to move goods across international boundaries, especially with the absence of tariffs in the customs union. This variable is positive yet statistically insignificant. Food in the average GCC market comes from both near and far. For example, a significant amount of Qatar's food is from the United Arab Emirates and Oman, both GCC countries that do not share a land border with Qatar. Similarly, large amounts of food originate from Saudi Arabia, a country that shares a land border with Qatar.

With the inauguration of the GCC customs union, expectations rose of increased intra-GCC trade, as is usually the case with customs unions. In this study, the effect of GCC membership on food exports is counterintuitively negative, but not significantly different from zero. Clearly, membership in the GCC customs union did not lead to a significant increase in food exports among member countries. Quite possibly, there were already large amounts of food exports within the GCC, buoyed by extremely low levels of taxation, a common heritage, common language, cross-border familial relationships, and limited non-tariff barriers. The customs union merely formalized the state of trade affairs.

In this study and in much of the literature, relative factor endowments and the countries' demand structures are represented by differences in per capita GDP. Large differences in factor endowments could lead to large volumes of trade (Helpman 1987), as countries focus on the production (and export) of goods for which there is an abundance of resources. This is a postulate of the Heckscher-Ohlin trade theory. However, this is not always the case. In Table 4, the variable is negative and highly statistically significant. This indicates that smaller differences in factor endowments are happening as 
aggregate GDP positively drives food exports. This finding is also in agreement with the Linder Hypothesis on international trade, which holds that as demand structures between countries become more similar, trade between them will increase. Ferto and Jambor (2015) confirmed that relative factor endowments are drivers of Hungarian agri-food trade with the EU, especially as relative factor endowments become similar between trading partners. This, too, is in agreement with the Linder Hypothesis. GCC countries are generally wealthy and per capita GDP values tend to converge, except for Qatar, whose per capita GDP has increased rather exponentially and diverged from the rest of the GCC in recent years.

There is a preponderance of fixed exchange rate regimes among GCC countries; the currencies are pegged to the U.S. dollar, except for Kuwait, which replaced the U.S. peg with a basket of currencies in 2010. U.S. dollar exchange rates are thus mostly invariant over time, so we opted for the ratio of nominal effective exchange rates because food export decisions are not necessarily made in isolation from trade in other commodities. Depreciation in the exporters' currency will be captured by a depreciating nominal effective rate. Similarly, if the value of the domestic currency appreciates, the value of the nominal effective exchange rate will also appreciate. As postulated, food exports become more competitive when the domestic currency depreciates, relative to the foreign currency. Accordingly, the exchange rate variable is positive, reflecting a depreciation in the nominal effective exchange rate of the food exporter, and hence a positive impact on food exports. The magnitude of the potential impact is considerably larger than the impacts of other independent variables in the model, perhaps a reflection of the stickiness of exchange rates in this region or merely capturing the larger trade effect. The second Hausman-Taylor estimator (Hausman-Taylor estimator (2)), which excludes import country population as an explanatory variable, revealed coefficients that were nearly similar to the first model.

\section{Determinants of GCC food exports}

The GCC is by far a net food importer in almost all food categories, including nearly $100 \%$ of wheat and other cereals. The larger Arab region imports nearly $56 \%$ of the cereal calories consumed (World Bank/FAO 2012). Consequently, a model of food exports by GCC countries is likely to be fraught with analytical problems because GCC food exports are sometimes intermittent, with relatively low export values. For example, whereas the Sargan-Hansen test $\left(\chi^{2}=202.103\right.$; $p$-value $\left.=0.0000\right)$ revealed in Table 5 that the fixed-effects estimator is more appropriate, the Hausman-Taylor estimator-i.e. Hausman-Taylor (1) - produced counterintuitively large parameter estimates for distance and the contiguous border effect, although the model was determined as properly identified. 
To resolve this matter, we dropped the import country population from the model because it had a correlation coefficient of 0.4830 with total GDP. Unfortunately, the overidentification test revealed that one or both exogenous variables in the reduced model-i.e. Hausman-Taylor (2), customs union and distance-may not be sufficiently exogenous or correlated with the fixedeffects term. That result notwithstanding, we proceeded with the interpretation of the relationship between GCC food exports and its main determinants-total GDP, customs union membership, and exchange rate. In reality, we believe both variables are exogenous, and this is confirmed in HausmanTaylor (1) model, where they constitute the subset of exogenous variables that were confirmed as being exogenous by the Sargan-Hansen test.

In the Hausman-Taylor (2) model, both distance and the relative factor endowment variables are not statistically significant. GCC food exports go to countries as far away as Argentina, Brazil, Australia, and New Zealand. With developments in transportation, such as almost daily flights by Gulf Carriers Emirates, Etihad, and Qatar Airways to some of the export destinations, distance no longer seems to hold the same level of importance as before. Similarly, GCC countries export food and ordinarily trade with many countries, some of whom have similar factor endowments to GCC countries, while factor endowments in others are substantially dissimilar. It is possible for GCC trade and export activities to coincide with the Linder Hypothesis or with the Heckscher-Ohlin theory, without necessarily being driven by either constructs. The net result is that relative factor endowment does not explain why GCC countries export food to other countries outside of the GCC region.

Total GDP is again positive and highly statistically significant. Compared with the intra-GCC model, the coefficient of approximately 1.34 reveals that the change in food export trade per unit change in total GDP is more than proportionate. Income has a stronger impact on GCC food exports to the rest of the world than was observed with intra-GCC food exports. Acceding to the customs union appeared to have decreased food exports from the GCC. The coefficient is expectedly negative and statistically significant. Removal of the last vestiges of trade barriers, backed by rising populations, higher incomes, and conspicuously higher market prices in some GCC countries such as Qatar, may have played a large role in diverting trade away from countries external to the GCC.

Exchange rate is statistically significant and the coefficient is negative. Importers generally have an insatiable demand for U.S. dollars needed to pay for imports. Rising demand for U.S. dollars tends to lead to appreciation in the value of the U.S. dollar, unless, of course, there is an exact corresponding increase in the supply of U.S. dollars by affected central banks. As the U.S. dollar appreciates in value, almost all GCC countries will record an appreciation in the values of their domestic currencies due to the 
fixed exchange rate regimes. The appreciation in GCC currencies explains the negative change in the value of GCC food exports relative to the ratio of bilateral exchange rates.

\section{Summary and conclusion}

This study evaluates some of the determinants of food exports within the GCC customs union, as well as food exports from the GCC customs union. Due to the relatively harsh climate, and limited amounts of agricultural water and arable land, GCC countries are generally net food importers. However, some countries, such as Oman, the United Arab Emirates, and Saudi Arabia, produce significant amounts of food. The GCC customs union came into effect on January 1, 2003, and has characteristics that may be different from many others. It brings together six countries in a relatively smaller region which is characterized by cross-border familial relationships, similar language, culture, and religious considerations that have long kept taxes low or non-existent, fixed exchange rate regimes, and extremely limited resources for food production. Under these circumstances, the study evaluates the impact of some main economic variables on intra-GCC food exports as well as GCC food exports to the rest of the world. Data for this study were assembled from UN COMTRADE, World Bank, International Monetary Fund, and Reuters for six GCC countries from 1995 to 2014. An unbalanced panel dataset was developed. Panel data techniques were used to develop and estimate the econometric models. For each set of analyses, the SarganHansen test revealed that the random-effects estimator was not consistent. Consequently, we estimated the parameters using the Hausman-Taylor estimator. This is consistent with econometric logic in trade models, which suggests that individual specific random disturbances in panel data are routinely correlated with regressors, making the fixed-effects estimator not only consistent and unbiased, but also efficient.

Results reveal that incomes are positively, statistically significant determinants of food export in both models. In agreement with the standard gravity model, the value of trade is directly proportional to the sizes of the economies of the trading partners. However, distance appears to have lost its role as a major determinant of trade. Unsurprisingly, developments in transportation technologies, including long-haul flights and refrigerated compartmentalized shipping, have reduced the negative effect of distance on trade.

In the intra-GCC export model, membership in the customs union has little effect on food exports. However, GCC membership appeared to have reduced the amount of GCC food exported to countries outside of the GCC. Noting these differences, a future study on trade creation and trade diversion enabled by the customs union is in order for food and other commodities. 
Factor endowments among GCC countries are generally quite similar to each other, and this seems to be fueling intra-GCC food exports. The results are in conformity with the Linder Hypothesis, which posits that countries trade with each other when their factor endowments become more similar. For food exports to countries outside of the GCC region, relative factor endowment is not a significant determinant. The GCC countries with similar factor endowment are trading with many different countries, some with similar factor endowments and others with dissimilar factor endowments. Food exports by GCC countries may thus sometimes coincide with the Linder Hypothesis and, in other cases, with the Heckscher-Ohlin theory, but none of these concepts is driving international food exports.

Exchange rates are major determinants of food exports. Due to the preponderance of fixed exchange rate regimes, we used the ratio of nominal effective exchange rates as the measure of exchange rate in the intra-GCC model. In the intra-GCC models, depreciation in the nominal effective exchange rates is positively related to food exports. In the GCC food export model, the ratio of bilateral exchange rates also has a significant effect on food exports. The negative effect merely reflected the strengthening nature of GCC currencies due to increasing demand for the U.S. dollar by food importing countries.

Our investigation has been limited by data availability. However, if data become available, an additional extension of this study will be to assess how the envisaged domestic and overseas investments in food production, especially by the richest GCC countries, affect the intra-GCC trade. Moreover, examining the impacts of major shifts in regional and global trade agreements (such as TTIP) will also be a valuable addition. This study's findings, though not underestimating the importance of the GCC customs union, imply that, besides trade policy and agreements, structural developments that boost member countries' production and income remain key to increase food purchase and trade.

\section{Funding}

This publication was made possible by the NPRP award (NPRP 6-064-4-001) from the Qatar National Research Fund (a member of the Qatar Foundation). The statements made herein are solely the responsibility of the authors.

\section{References}

Alpen Capital. 2015. GCC Food Industry Report. Dubai, UAE: Alpen Capital Investment Banking.

Amemiya, T., and T. E. MaCurdy. 1986. "Instrumental-Variable Estimation of an ErrorComponents Model.” Econometrica 54 (4):869-80. doi:10.2307/1912840. 
Anderson, J. E., and E. van Wincoop. 2003. "Gravity with Gravitas: A Solution to the Border Puzzle.” American Economic Review 93 (1):170-92. doi:10.1257/000282803321455214.

Bergstrand, J. H. 1985. "The Gravity Equation in International Trade: Some Microeconomic Foundations and Empirical Evidence." Review of Economics and Statistics 67 (3):474-81. doi:10.2307/1925976.

Bojnec, S., and I. Ferto. 2016. "Patterns and Drivers of the Agri-Food Intra-Industry Trade of European Union Countries." International Food and Agribusiness Management Review 19 (2):53-74.

Cipollina, M., and L. Salvatici. 2010. "The Trade Impact of European Union Agricultural Preferences." Journal of Economic Policy Reform 13 (1):87-106. doi:10.1080/ 17487870903546259.

Economist Intelligence Unit. 2010. The GCC in 2020: Resources for the Future. Doha, Qatar: Qatar Financial Center Authority.

Egger, P., and M. Pfaffermayr. 2003. "The Proper Panel Econometric Specification of the Gravity Equation: A Three-Way Model with Bilateral Interaction Effects." Empirical Economics 28 (3):571-80. doi:10.1007/s001810200146.

Ferto, I., and A. Jambor. 2015. "Drivers of Vertical Intra-Industry Trade: The Case of the Hungarian Agri-Food Sector." Agricultural Economics 46:113-23. doi:10.1111/ agec.2015.46.issue-1.

Furtan, W. H., and B. M. van Melle. 2004. "Canada's Agricultural Trade in North America in North America: Do National Borders Matter?" Review of Agricultural Economics 26 (3):317-31. doi:10.1111/j.1467-9353.2004.00182.x.

Ghazalian, P. L., B. Larue, and J. P. Gervais. 2011. "Assessing the Implications of Regional Preferential Market Access for Meat Commodities.” Agribusiness 27 (3):292-310. doi:10.1002/agr.20274.

Hallak, J. C. 2010. "A Product-Quality View of the Linder Hypothesis." The Review of Economics and Statistics 92 (3):453-66. doi:10.1162/REST_a_00001.

Hansen, L. P. 1982. "Large Sample Properties of Generalized Method of Moments Estimators.” Econometrica 50 (4):1029-54. doi:10.2307/1912775.

Hausman, J. A. 1978. "Specification Tests in Econometrics.” Econometrica 46 (6):1251-71. doi:10.2307/1913827.

Hausman, J. A., and W. E. Taylor. 1981. "Panel Data and Unobservable Individual Effect." Econometrica 49 (6):1377-98. doi:10.2307/1911406.

Helpman, E. 1987. "Imperfect Competition and International Trade: Evidence from Fourteen Industrialized Countries." Journal of the Japanese and International Economies 1:62-81. doi:10.1016/0889-1583(87)90027-X.

Jámbor, A. 2014. "Determinants of Intra-Industry Agri-Food Trade in the Visegrad Countries." Acta Alimentaria 43 (2):246-53. doi:10.1556/AAlim.43.2014.2.8.

Jayasinghe, S., and R. Sarker. 2008. "Effects of Regional Trade Agreements on Trade in Agrifood Products: Evidence from Gravity Modeling Using Disaggregated Data." Review of Agricultural Economics 30 (1):61-81. doi:10.1111/raec.2008.30.issue-1.

Lambert, D., and S. McKoy. 2009. "Trade Creation and Diversion Effects of Preferential Trade Associations on Agricultural and Food Trade." Journal of Agricultural Economics 60 (1):17-39. doi:10.1111/jage.2008.60.issue-1.

Linder, S. 1961. An Essay on Trade and Transformation. Stockholm, Sweden: Almqvist and Wiksell.

McCallum, J. 1995. "National Borders Matter: Canada-U.S. Regional Trade Patterns." American Economic Review 85 (3):615-23.

McMillan, J., and E. McCann. 1981. "Welfare Effects in Customs Unions." The Economic Journal 91 (363):697-703. doi:10.2307/2232833. 
Okabe, M., and S. Urata. 2014. "The Impact of Afta on Intra-Afta Trade." Journal of Asian Economics 35:12-31. doi:10.1016/j.asieco.2014.09.004.

Olper, A., and V. Raimondi. 2009. "Patterns and Determinants of International Trade Costs in the Food Industry." Journal of Agricultural Economics 60 (2):273-97. doi:10.1111/ jage.2009.60.issue-2.

Ornelas, E. 2007. “Exchanging Market Access at the Outsiders' Expense: The Case of Customs Unions." Canadian Journal of Economics 40 (1):207-24. doi:10.1111/j.13652966.2007.00405.x.

Plumper, T., and V. Troger. 2007. "Efficient Estimation of Time Invariant and Rarely Changing Variables in Panel Data Analysis with Unit Effects." Political Analysis 15 (2):124-39. doi:10.1093/pan/mpm002.

Qatar National Food Security Programme (QNFSP). 2013. The National Food Security Plan. Doha, Qatar.

Qatar Statistics Authority (QSA). 2012. “Qatar Food Imports, 2011.” http://www.qix.gov.qa/ portal/page/portal/qix/subject_area?subject_area=332.

Robinson, S., and K. Thierfelder. 2002. "Trade Liberalization and Regional Integration: The Search for Large Numbers." Australian Journal of Agricultural and Resource Economics 46 (4):585-604. doi:10.1111/1467-8489.t01-1-00057.

Sargan, J. D. 1958. "The Estimation of Economic Relationships Using Instrumental Variables.” Econometrica 26 (3):393-415. doi:10.2307/1907619.

Serlenga, L., and Y. Shin. 2007. "Gravity Models of Intra-EU Trade: Application of the CCEPHT Estimation in Heterogeneous Panels with Unobserved Common Time-Specific Factors." Journal of Applied Econometrics 22 (2):361-81. doi:10.1002/(ISSN)1099-1255.

Sun, L., and M. R. Reed. 2010. "Impacts of Free Trade Agreements on Agricultural Trade Creation and Trade Diversion." American Journal of Agricultural Economics 92 (5):135163. doi:10.1093/ajae/aaq076.

Syropoulos, C. 1999. "Customs Unions and Comparative Advantage." Oxford Economic Papers 51 (2):239-66. doi:10.1093/oep/51.2.239.

Tinbergen, J. 1962. Shaping the World Economy: Suggestions for an International Economic Policy. New York, NY: The Twentieth Century Fund.

Williamson, J., and A. Bottrill. 1971. "The Impact of Customs Unions on Trade in Manufactures." Oxford Economic Papers 23 (3):323-51.

World Bank/FAO. 2012. The Grain Chain: Food Security and Managing Wheat Imports in Arab Countries. Washington, DC: World Bank.

Yu, E. S., and G. W. Scully. 1975. "Domestic Distortions and the Theory of Customs Unions." Southern Economic Journal 42 (2):218-24. doi:10.2307/1056770. 